\title{
"Esse universo dos sons que a gente não escuta": entrevista com Cildo Meireles
}

\author{
"That Universe of Sounds that We Don't Listen to": \\ interview with Cildo Meireles \\ "Ese universo de sonidos que no escuchamos": \\ entrevista con Cildo Meireles
}

Caroline Alciones de Oliveira Leite (Universidade Federal do Rio de Janeiro, Brasil) *

https://doi.org/10.22409/poiesis.v21i36.42766

RESUMO: Desde janeiro de 2019, temos tido a oportunidade de realizar uma série de entrevistas com Cildo Meireles, além de outras visitas ao ateliê do artista. Esta entrevista, a primeira da série, trata do sonoro em diversas obras de Cildo Meireles, desde o final da década de 1960 até a década de 2010. O desenrolar da entrevista se dá entremeado por reticências que contemplam conversas paralelas à questão sonora e também muitas risadas com o artista e seus assistentes.

PALAVRAS-CHAVE: arte contemporânea; som; Cildo Meireles

* Caroline Alciones de Oliveira Leite é doutoranda do Programa de Pós-Graduação em Artes Visuais da Escola de Belas Artes da UFRJ. E-mail: carolinealciones@gmail.com. Orcid: https://orcid.org/0000-0002-7866-7863 
ABSTRACT: Since January 2019, we have had the opportunity to conduct a series of interviews with Cildo Meireles, in addition to other visits to the artist's studio. This interview, the first in the series, deals with the sound in several works by Cildo Meireles, from the end of the 1960s to the decade of 2010. The interview unfolds with reticence that contemplates parallel conversations to the sound question and also much laughter with the artist and his assistants.

KEYWORDS: contemporary art; sound; Cildo Meireles

RESUMEN: Desde enero de 2019, hemos tenido la oportunidad de realizar una serie de entrevistas con Cildo Meireles, además de otras visitas al estudio del artista. Esta entrevista, la primera de la serie, aborda el sonido en varias obras de Cildo Meireles, desde finales de la década de 1960 hasta la década de 2010. La entrevista se desarrolla con reticencias que contemplan conversaciones paralelas a la pregunta del sonido y también muchas risas con el artista y sus asistentes.

PALABRAS CLAVE: arte contemporáneo; sonido; Cildo Meireles

Recebido: 19/5/2020; Aprovado: 8/6/2020; Publicado: 1/7/2020

Citação recomendada:

LEITE, Caroline Alciones de Oliveira. "Esse universo dos sons que a gente não escuta": entrevista com Cildo Meireles. Revista Poiésis, Niterói, v. 21, n. 36, p. 175-206, jul./dez. 2020. [https://doi.org/10.22409/poiesis.v21i36.42766]

(cc) BY-NC-ND Este documento é distribuído nos termos da licença Creative Commons Atribuição-NãoComercial 4.0 Internacional (CC-BY-NC) (c) 2020 Caroline Alciones O. Leite

Caroline Alciones de Oliveira Leite, "Esse universo dos sons que a gente não escuta”: entrevista com Cildo Meireles. 


\section{"Esse universo dos sons que a gente não escuta": entrevista com Cildo Meireles}

Caroline Alciones - Agradeço por você me receber em seu ateliê para esta entrevista ${ }^{1}$. Conforme já conversamos, minha pesquisa de mestrado girou em torno de questões trazidas por Através. (Fig. 1) No processo de pesquisa de sua obra, as questões relativas ao som têm me intrigado de forma crescente, algo que passei a investigar com dedicação crescente no doutorado². Assim, eu gostaria de começar entendendo como teve início seu interesse pelo som e quando você se deu conta da questão sonora em relação à sua obra.
Cildo Meireles - Acho que as coisas começaram, mais consistentemente, a partir de 1969/70. E começaram, de alguma maneira, por causa do interesse em topologia. Eu achava que, de repente, com o som seria mais fácil abordar questões ditas topológicas. Eu acho que esse interesse depois se ampliou. Me lembro de uma aula quando eu estava no primeiro ano científico, na época, em Brasília, no Elefante Branco, e do professor de música, Reginaldo de Carvalho. A gente tinha aula de música com ele, que era pesquisador ligado à música eletrônica, à música concreta, tinha feito a formação na França, na Rádio e Televisão Francesa, e teve como profes- 


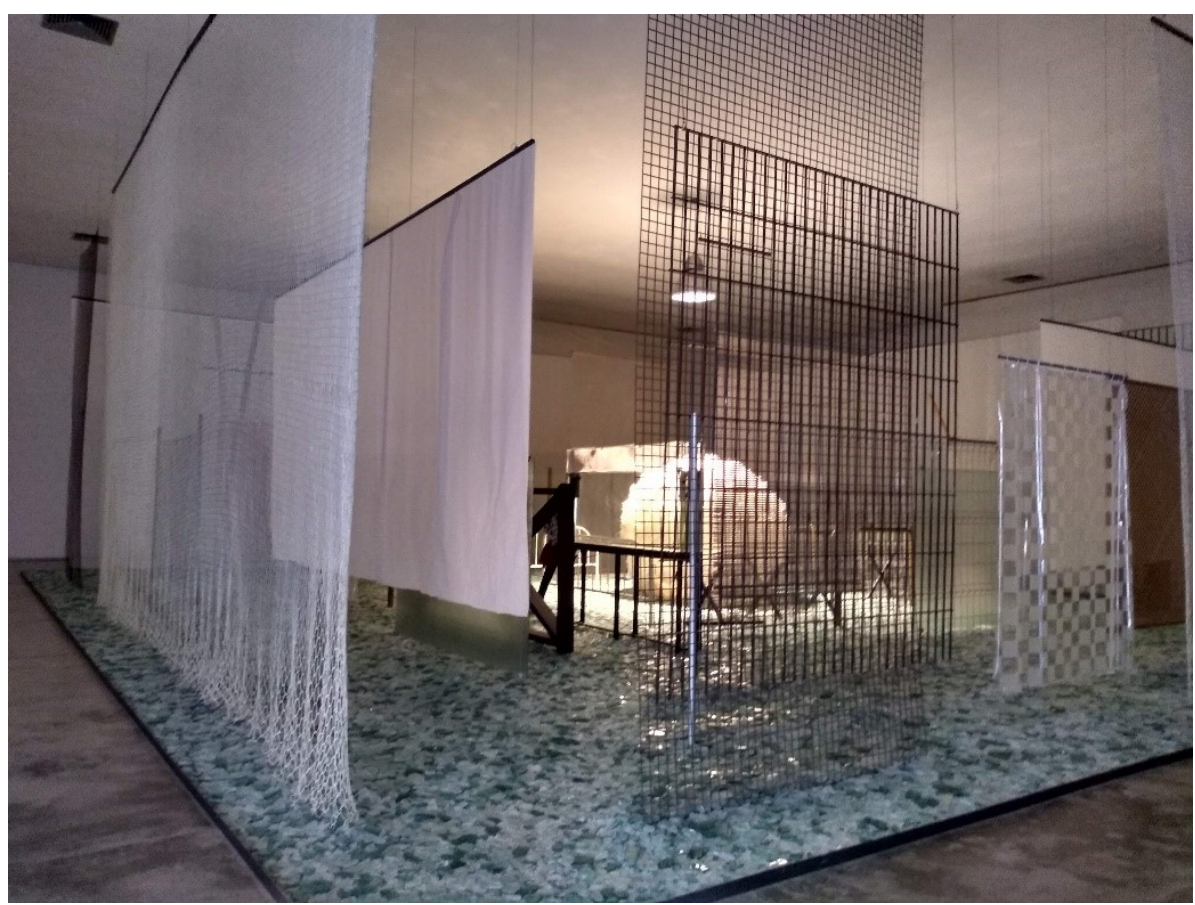

Fig. 1 - Cildo Meireles, Através, 1983-1989.

Instituto Inhotim, Brumadinho, MG

(Foto: Caroline Alciones; Fonte: Arquivo pessoal da autora) 
sores todo um pessoal ligado à vanguarda musical da época, [Arnold] Schönberg e outros músicos... Mas o Reginaldo, naquela aula, falou o seguinte: que justamente naquele momento em que ele esteve lá [na França], tinha um grupo que estava desenvolvendo uma pesquisa, recuperando sons gravados em cerâmica, essa cerâmica utilitária. Então, se tiver algum som perto do oleiro na hora em que ele estiver fazendo um vaso, uma coisa assim...

Caroline Alciones - O som fica gravado?

Cildo Meireles - Sim. Eles estavam recuperando os sons provenientes desse tipo de coisa. Se tivesse um cara fazendo, por exemplo, um jarro cilíndrico e tivesse Cristo no Sermão da Montanha, por exemplo, você teria a voz de Cristo. Isso é uma coisa pela qual eu sempre me interessei; todo esse universo dos sons que a gente não escuta, o subsom, o ultrassom. Então, eu acho que o som é uma coisa que tem que ser percebida, porque são essas ondas que interessam para algumas questões que o trabalho tem. $E$ tem muitos [sons], na verdade tem...
Caroline Alciones - A primeira obra em que eu percebo o som está dentro de sua série de Estudos ${ }^{3}$ e de uma forma bastante singular, pois trata-se de um texto datilografado, porém repleto de sons.

Cildo Meireles - Sim. Uma delas é Estudo para Espaço. (Fig. 2) Esse texto se refere exatamente ao som... talvez tenha sido a primeira, não?

Caroline Alciones - É de 1969, você falou justamente esse período 1969/70...

Cildo Meireles - Final de 1969. Eu mandei esse trabalho para o Salão da Bússola na categoria gravura, mas depois tem [outros...]

[...]

Mas já na primeira instalação, quer dizer, como projeto, talvez tenha sido em Desvio para o Vermelho em 1967. Eu acho. Como projeto, como ideia, a primeira [obra com som] acabou sendo a primeira parte [do Desvio para o Vermelho], que é Impregnação. Foi na mesma época de Espaços virtuais; eu estava mais focado nos Espaços virtuais, cujas maquetes foram comidas pelos cupins no ateliê de Santa Teresa. Mas enfim... aí começa a aparecer o som; 
Fig. 2 - Cildo Meireles, Estudo para Espaço, 1969.

(Fonte: Catálogo da exposição Entrevendo: Cildo Meireles, Sesc Pompeia, SP) 
a partir da primeira peça que foi o Eureka/Blindhotland. De início, começou a ser pensada com essa parte que é o Expeso. ${ }^{4}$

Caroline Alciones - Que eram as esferas caindo?

Cildo Meireles - Isso, a diferença entre alturas, as diferentes distâncias do microfone e os diferentes pesos, tinham esses três fatores.

Caroline Alciones - Paralelamente ao Eureka/Blindhotland, teve também o Sal sem Carne...

Cildo Meireles - É, foi junto. Eu já tinha feito Mebs/Caraxia, em 1970/71. Eu estava viajando, mas aí apareceu uma série de projetos ligados a som, porque eu achava que, por exemplo, talvez o som fosse a melhor maneira de abordar certas questões topológicas porque não tinha lado. Ele era, vamos dizer, mais neutro. E agora, poucos anos atrás, eu descobri que o Möbius, na verdade, não foi o primeiro que propôs aquela estrutura de torção, foi um outro matemático ${ }^{5}$, mas quem acabou ficando com a glória foi o Möbius. Depois disso, de uma maneira geral, o som tem me acompanhado. Além de ter tido toda uma série de projetos, já que eu queria fazer discos de terra, discos de pedra, discos, enfim, tem diferentes discos, tem o disco do tempo que eu comecei a avançar em 1977, num hotel de Brasília. Coisas assim. Até discos que eram já feitos, ready-made-records, tipo essas lâminas de lixadeiras, abrasivas. Mas aí o som, de certa maneira, foi se incorporando. No Sermão da Montanha, ele é um constituinte estrutural mesmo. O som [da lixa] simulava um fósforo sendo riscado. Isso foi em 1979.

Caroline Alciones - A ideia do atrito em $O$ Sermão da Montanha aparece também em outras obras como Três Sonidos e Através, mas há também nessas obras, assim como em Cigarra, uma certa necessidade da presença do sujeito para que o som aconteça. Como foi o contexto de criação de Cigarra?

Cildo Meireles - Rubens, tem aí aquela Cigarra? Elas ficaram soterradas em um desmoronamento que teve em Friburgo. Elas estavam prontas, só faltava encaixar a figura na lâmina de aço que fazia o som. Mas é um trabalho que eu pensei assim: 
na Cinelândia cheia de pessoas ou embaixo ali do MAM, que tem uma acústica assim muito especial. Fiz [Cigarra] em uma exposição que foi em homenagem ao Frederico [Morais] por aqueles Domingos da Criação. Eu acabei não participando muito desses Domingos. Foi um ano que eu estava muito egoísta. Foi um ano em que teve muitos projetos, muitos trabalhos. Me pediram uma coisa assim, e aí eu resolvi fazer esse projeto. Era um projeto ligado ao som, seria pelo Domingo do Som. Então...

[Rubens entrega uma Cigarra para Cildo, que produz o som.] (Fig. 3)

Mas elas ficaram desmontadas; essa parte aqui, que entra depois, encaixa nesse casco. Na época em que fiz a obra, as peças estavam lá na oficina do Gerônimo. Tudo que é de metal, é ele que faz para mim. Mas teve aquele desabamento, elas ficaram soterradas, ficaram lá sob a lama, em 2010/2011. Isso você encontrava, nesse mês que passou, novembro ou dezembro, havia vários camelôs vendendo. As cigarras mesmo sumiram.
Como disse, dessa aqui tinha cerca de 7 mil prontas, a gente ia fazer $8 \mathrm{mil}$. Ele [Gerônimo] aprontou quase mil para o evento, para eu distribuir para as pessoas lá no MAM. Eu disse que tinha urgência e ele aprontou essas. As outras ele também aprontou, mas estavam lá em Friburgo, onde ele dava aula. Mas o barranco caiu e soterrou tudo. Isso eu tenho pena. Agora não dá nem para falar com o Gerônimo, porque as cigarras ficaram enterradas... Um dia alguém descobre.

Caroline Alciones - Se por um lado, muitas de suas obras são instalações que carreiam a ideia de pano-de-roda ${ }^{6}$, outras obras, como Cigarra, Liverbeatlespool e Elemento desaparecendo / Elemento desaparecido (passado iminente), transbordam para o espaço público. Você sente essa necessidade de ir para o espaço público? Quando essa questão aparece pela primeira vez em sua obra?

Cildo Meireles - É, tem em algumas peças. Olha só, em final de abril [de 1970], foi o primeiro final de semana aqui depois Do Corpo a Terra, em Belo Horizonte. Eu tinha feito Tiradentes: Totem Monumento ao Tabu. No primeiro fim de semana, a gente saiu

Caroline Alciones de Oliveira Leite, “Esse universo dos sons que a gente não escuta”: entrevista com Cildo Meireles. 


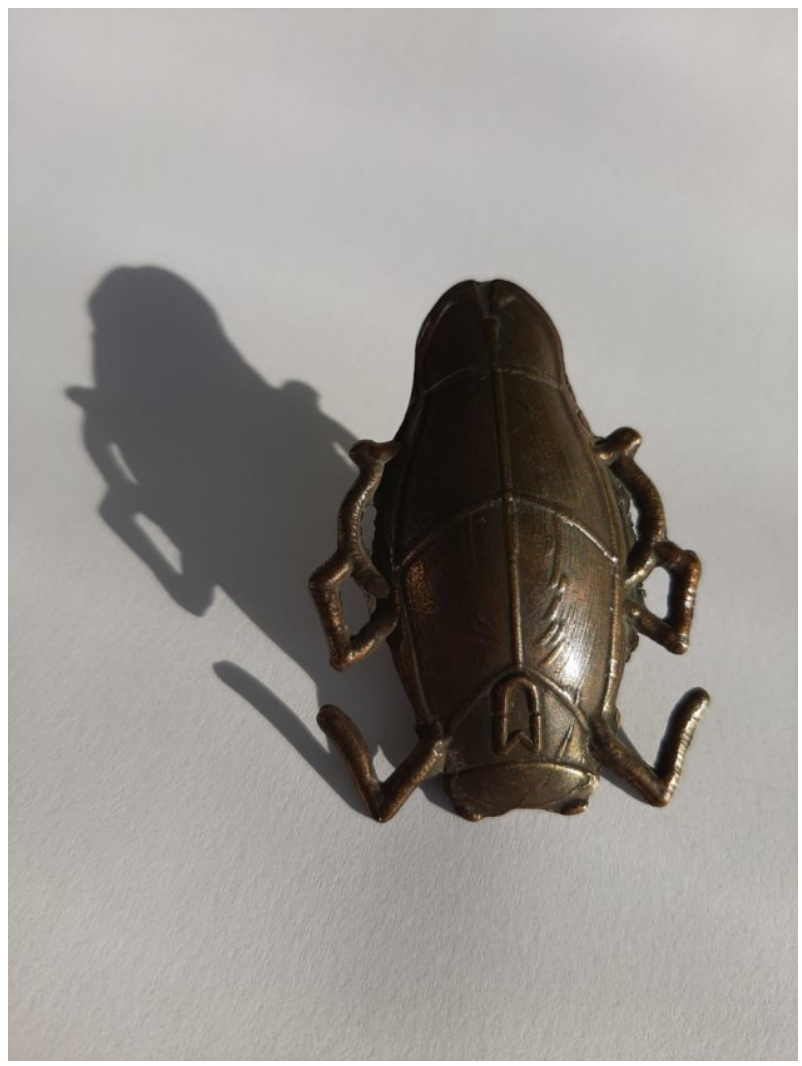

Fig. 3 - Cildo Meireles, Cigarra, 2010.

(Foto: Caroline Alciones; Fonte: Arquivo pessoal da autora)

Revista Poiésis, Niterói, v. 21, n. 36, p. 175-206, jul./dez. 2020. (https://doi.org/10.22409/poiesis.v21i36.42766) 
para pegar uma praia e a gente ia lá para a Prainha... $\mathrm{Na}$ volta, tinha um bar de madeira escamada, bem aqui no começo da Barra, quando você sai do túnel, assim à esquerda, perto do canal indo para o mar, e a gente sempre parava lá porque tinha um peixe sempre fresco, baratinho. No final do almoço, lá pelas três, quatro horas, as pessoas estavam à mesa conversando e alguém falou: "Poxa, você sabe que se um caroço de azeitona entrar em uma garrafa de Coca-Cola ou de cerveja, (sei lá) por meio do processo de lavagem industrial, por causa das leis da física, esse caroço não vai sair nunca dessa garrafa? Ele vai ser reenvasado, mas fica um caroço de azeitona ali." Eu achei aquilo interessante e quando eu cheguei em casa, no final da tarde, eu botei a [a ideia no papel]... até outro dia eu achei a cópia.

Esse é o começo das Inserções. Eu cheguei e fiz um texto e quando eu acabei de ler o texto, achei que não estava claro, aí eu resolvi dar dois exemplos: peguei a coisa da garrafa em si, é a coisa do meio circulante; e do dinheiro. Elas nasceram em decorrência de um texto, desse primeiro texto, e chegaram à rua por imposição própria... porque eu sempre pensei nisso como uma espécie de grafite circu- lante. Mas era um grafite que não era estático, era móvel; as Inserções, no caso.

Caroline Alciones - Fazendo um salto no tempo, mas continuando no espaço públi$\mathrm{co}$, a versão de Liverbeatlespool apresentada na exposição que aconteceu no Museu de Arte do Rio, Lugares do Delírio, que teve a curadoria da Tania Rivera, contou com o Dj Stylus Baratona levando sua obra pela Zona Portuária do Rio de Janeiro. Você chegou a ver sua obra em circulação pela Zona Portuária?

Cildo Meireles - Não. Para falar a verdade, naqueles momentos eu não sabia nem andar pelo Centro. Os caras mudaram tanto. O meu marco no Centro ali era mais de ir a pé, vindo da Cinelândia. Se eu o tivesse encontrado iria cobrar royalties, uma coisa como jingle para vender a bicicleta. Parecia a história do contrabando que o Stanislaw Ponte Preta conta7. Mas eu não encontrei esse cara [Dj Stylus Baratona]. (Fig. 4)

[...]

[Tem] o carrinho de picolé: Elemento desaparecendo/Elemento desaparecido (passado iminente) em São Paulo ${ }^{8}$. A prefeitura tinha baixado um decreto que proibia a 


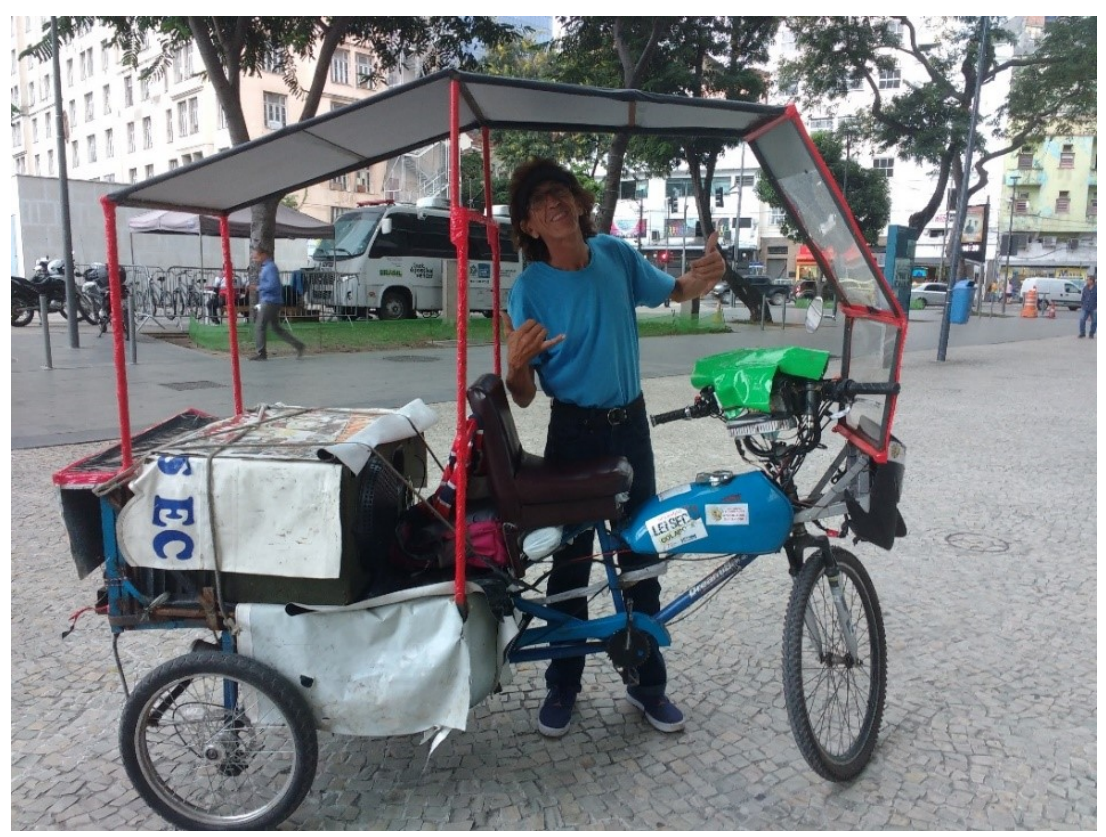

Fig. 4 - Cildo Meireles, Liverbeatlespool, 2014.

(Foto: Caroline Alciones; Fonte: Arquivo pessoal da autora) 
venda de produtos de fundo de quintal, carrocinha. Eles [os organizadores da Futuro do Presente] conseguiram que a venda dos picolés acontecesse nos parques; foi um carrinho cheio de picolés [Elemento Desaparecendo/Desaparecido] para aquela região do Parque Pompeu, alguma coisa assim. Aí chegou lá o cara com o carrinho, com logotipo, bandeirinhas, picolés, boné, e os vendedores de carrinho [da região] cercaram o cara e o expulsaram. [...] É o Brasil mesmo. É aquela coisa: só existe uma maneira de se fazer arte no espaço público: é arte contra o espaço público, tem que ser de surpresa. Os caras tentaram fazer dentro da lei e, claro, vira outra coisa. (Fig. 5)

[Mas antes] começou a vir um período de trabalhos com água.

Caroline Alciones - O próprio Desvio para o Vermelho tem o som da água.

Cildo Meireles - Que é importantíssimo, porque é ele que cria essa circularidade. É o primeiro som que você ouve. Antes de você entrar, você já começa a ouvir pela televisão, com detalhes em vermelho, e a última coisa que você ouve lá no final, quando você volta é isso. O som é importantíssimo no Desvio. Sendo que eu trabaIhei nisso em 1981/82, foi quando eu botei junto três coisas que estavam anotadas separadas, porque eram de épocas diferentes: Impregnação, Entorno e Desvio. Eu tinha pensado como peças autônomas e quando teve o convite de um museu do Texas $^{9}$, eu botei as três juntas pela primeira vez, porque eu achava interessante ter a peça de grande escala, onde era proposta assim... uma espécie de encadeamento de falsas lógicas, era isso que eu gostava nesses três projetos... tem a garrafinha, mas depois, nos anos 1990, eu fiz três peças com água.

Eu apresentei no Le Creux de L'Enfer ${ }^{10}$, em Thiers, duas peças com água: J'est un Autre, aquela coisa do Rimbaud, "eu é um outro", e o Chove Chuva, que agora a gente refez para a exposição que teve na Itália, na Galleria Continua ${ }^{11}$, há 6 anos. As duas são com água... duas inundações. Uma inundação braba foi com o Chove Chuva. [Próximo ao local da exposição], passava um rio embaixo de uma fábrica de Laguiole, esse canivete francês que tem uma abelha em cima e que são todos artesanais. São 800 artesãos na cidade. 


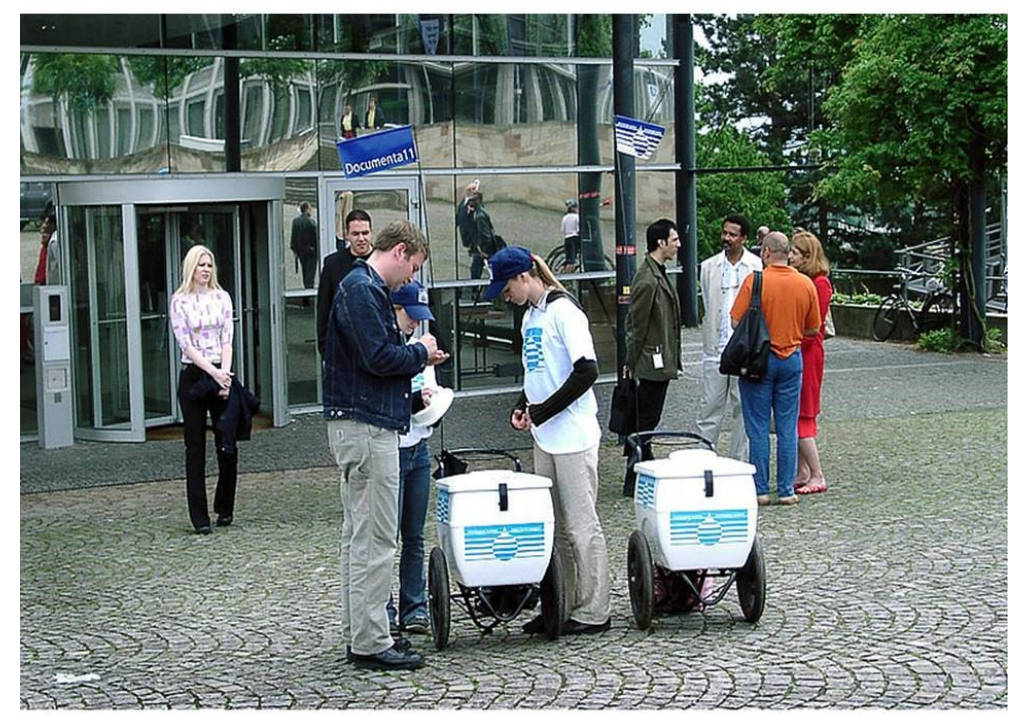

Fig. 5 - Cildo Meireles, Elemento desaparecendo/Elemento desaparecido (passado iminente), 2002. (Foto: Haupt e Binder; Fonte: http://universes-in-universe.de/car/documenta/11/ frid/e-meireles.htm) 
Na Idade Média, a economia da região era baseada na fabricação de papel e dessas faquinhas, que são poderosas. Passava o rio embaixo [da fábrica] e eles [os artesãos] iam ao rio para amolar a faca na mão. Tem o museu da faca nesse lugar. [A cidade] deve ter 3 mil habitantes e esse museu tem 700/800 visitantes por dia.

Caroline Alciones - Além de Desvio para o Vermelho e de Chove Chuva, a água aparece em obras como Estudo para tempo, Marulho, riooir, Abajour. Por que a água te ronda, há algum motivo em especial? Há outras obras em que a água seja um elemento constitutivo?

Cildo Meireles - Foi uma coincidência. Começou a ter... O último, que eu me lembre, foi de 2015/2016, o Aquaurum. São dois copos, um cheio de água em tensão superficial, ou seja, a capacidade que os líquidos têm de se manterem um nível acima da borda do copo. E um outro copo idêntico, mas cheio de ouro maciço. Eu devo mostrar o Aquaurum, se a coisa vingar mesmo, na Colômbia, em um lugar que eu acho incrível, que é o Museu do Ouro. Está programado para o ano que vem e o espaço disponibilizado é o Museu do Ouro. A gente brincava na [Galerie] Lelong $^{12}$ [onde exibi essa obra pela] primeira vez, há uns quatro/cinco anos, eu falei com a Mary: "você põe à venda, mas a gente vai vender o copo com água. E quem comprar o copo d'água ganha de brinde o copo com ouro maciço puro." o ouro é denso para chuchu. O ouro pesa mais do que chumbo. Um copinho daquele tem $8 \mathrm{~kg}$. Mas ninguém até agora quis beber dessa água. Se bem que em certos lugares da alta gastronomia, uns pratos têm uns traços de ouro...

[Cildo apresenta o catálogo Mango Discipline, publicado a partir da exposição $Q \& A$, realizada na Galleria Continua, em San Gimignano, Itália, com Trudo Engels ${ }^{13}$.]

Nessa exposição, fizemos uma versão de Chove Chuva que é high-tech, feita com meu amigo Trudo, um artista belga. (Fig. 6) Ele estava cuidando da refeitura do Chove Chuva, que havia sido feita pela primeira vez em Thiers, esse lugar da faca. Foi na primeira que vez inundou... Meia-noite, após a inauguração, depois do jantar, das bebidas, desmontamos toda a peça e tivemos que refazer tudo, porque o silicone estava todo errado. 


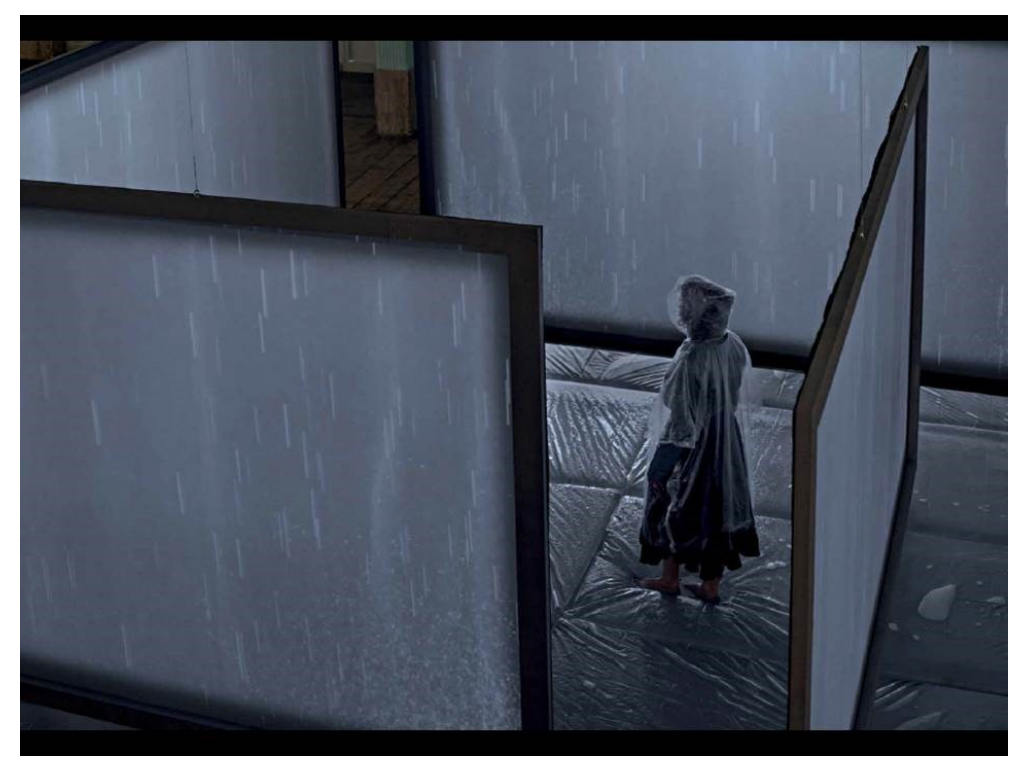

Fig. 6 - Cildo Meireles, Chove Chuva, 1995-2015

Galleria Continua, San Gimignano (Itália)

(Fonte: Mango Discipline, 2018)

Revista Poiésis, Niterói, v. 21, n. 36, p. 175-206, jul./dez. 2020. (https://doi.org/10.22409/poiesis.v21i36.42766) 
[Folheando o catálogo Mango Discipline]

São quatro capítulos [no catálogo] ${ }^{14}$. No meu caso, [a água] é o Chove Chuva e o Aquaurum. A ideia da exposição era exatamente Question and Answer/Questão e Resposta. Ele [Trudo] fazia trabalhos que se relacionavam com os meus. Tem um, por exemplo, um trabalho que ele fazia com pérolas. Ele começou a comer as pérolas e, no total, foram 3 mil pérolas. Esse trabalho se relacionava com o Aquaurum. Ele comia essas pérolas e depois as coletava, mas não era assim apenas 10 ou 20. de mostrar [a obra], ele começou a comer [as pérolas] aos punhados. Conclusão: ele depois fazia colares [com as pérolas coletadas nas fezes]; enfim... tem algumas imagens no catálogo. (Fig. 7) Para celebrar o final das 3 mil, ele resolveu comer um pequeno diamante, que ele nunca mais encontrou.

[Vendo o catálogo da mostra Mango Discipline, aparece Chove Chuva.]

O legal é que [Chove Chuva] é uma peça de verão, eu gosto de dizer. Então é legal entrar de short. Mas essa [obra] agora

tem sensor de presença. Tem distribuição. É toda controlada. Eu fiz uma água seca, que foi o Marulho.

Caroline Alciones - Marulho, além de apresentar uma água seca, uma espécie de miragem, apresenta também, a partir da água, um dado polifônico, diante da repetição da palavra "água" em diversas línguas e vozes. Como foi o processo de execução dessa obra e de captação de seu áudio?

Cildo Meireles - Está sendo. Toda oportunidade que tenho. A primeira vez foi na África do Sul, em Johanesburgo, na Bienal ${ }^{15}$, um lugar piradíssimo. No começo era uma fita, tinha tantas línguas, idiomas básicos, inglês, francês, alemão, latim, depois quando eu fiz a segunda vez, em Brasília, a gente adicionou mais vozes, porque lá havia as embaixadas da Europa, línguas indígenas, então a gente tem cerca de quase cem. Mas eu ainda vou chegar a um departamento de Etimologia, de línguas, onde tenha arquivo... É uma colagem que eu vou fazendo aos poucos, procurando melhorar tecnicamente também a qualidade. A primeira vez foi $K 7$, em 1997. 


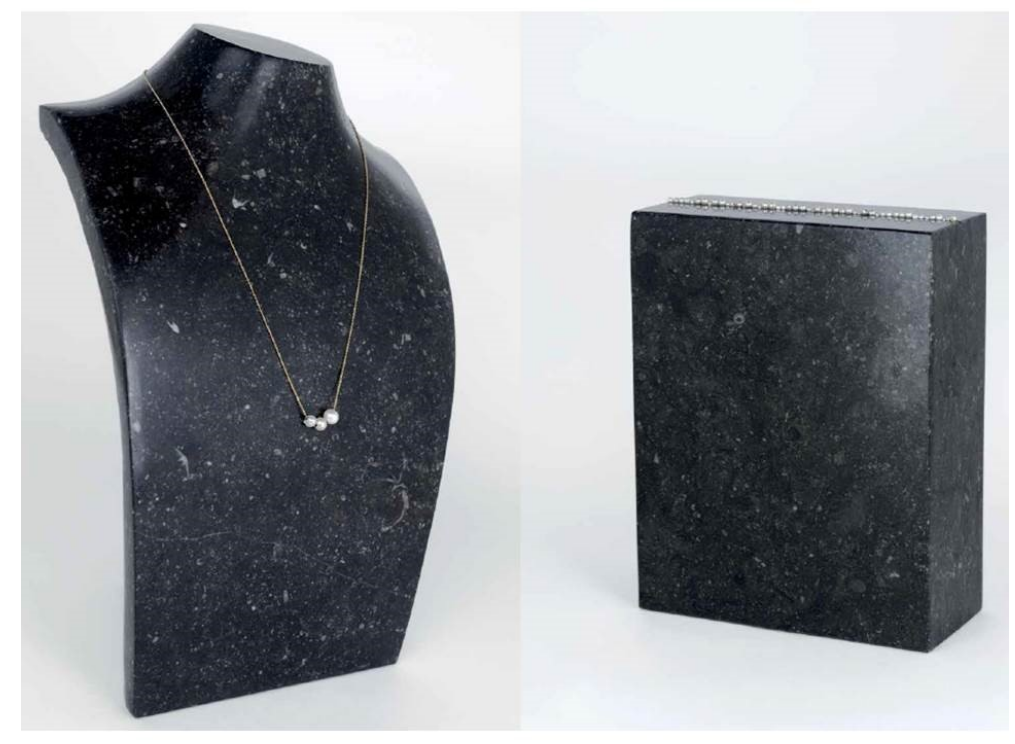

Fig. 7 - Various Artists, aza.Pearl, 2014-2015.

(Fonte: Mango Discipline, 2018)

Revista Poiésis, Niterói, v. 21, n. 36, p. 175-206, jul./dez. 2020. (https://doi.org/10.22409/poiesis.v21i36.42766) 
Teve o Elemento desaparecendo / Elemento desaparecido (passado iminente) que, aí, era uma espécie de água escancarada.

Caroline Alciones - Em riooir você também recorre à água que, talvez, possibilite uma leitura política a partir da questão das águas residuárias, como você chegou a mencionar em outras ocasiões. Mas há também uma dimensão poética bastante contundente, novamente a partir de uma polifonia construída na aglomeração das risadas de pessoas que não vemos e que, sem a capa do disco, não é possível saber de quem são as tantas risadas que nos rodeiam. A obra já tinha essa configuração desde a sua concepção na década de 1970 ?

Cildo Meireles - No começo era um projeto simples. Esse projeto é de 1976; a gente estava morando em Petrópolis, mas fora da cidade, antes do Quitandinha; era um lugar em que um amigo meu, um artista, o Gastão, construiu. Era um lugar muito legal, que ficava antes da polícia rodoviária, [da Casa] do Alemão. É um projeto que nasceu a partir da palavra, desse palíndromo. E aí eu pensei, para ilustrar o oir ${ }^{16}$, em fazer uma colagem com trechos comprados em arquivos de som, de estúdio, [produzidos] comercialmente para sonoplastia de filmes... desde o mais imperceptível som de água, que iria aumentando, aumentando, aumentando, até os limites que seriam, aqui no Brasil, para rio de água doce, isso em 1976, a Pororoca e o Iguaçu. Porque o Brasil tem três bacias hidrográficas - Rio Paraná/Prata, Amazonas e São Francisco.

[...]

Então, no início era isso. Do outro lado, eu queria usar uma bolsa de risos, sabe? Dessas que custavam 1 dólar, e quando você abria tinha uma K7 bem fajuta com o som de uma risada. [...]

Caroline Alciones - Você dialogou com João Guimarães Rosa no conto $A$ terceira margem do rio?

Cildo Meireles - A montagem final até ficou parecendo isso ${ }^{17}$. Mas o trabalho final é o disco. (Fig. 8)

Caroline Alciones - E como se deu a incorporação da questão da água residuária à obra, considerando que a obra partiu do palíndromo riooir? 


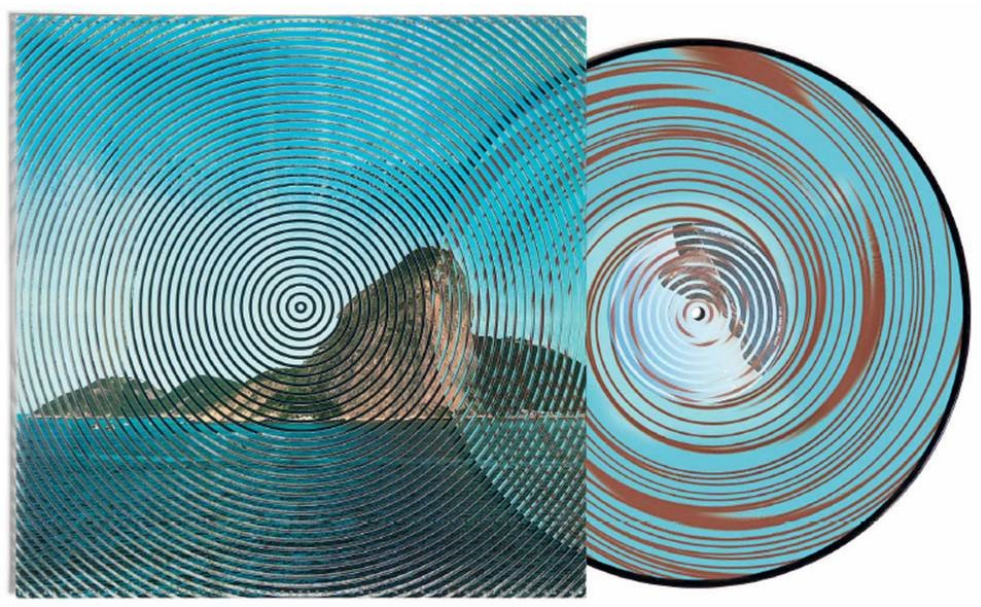

Fig. 8 - Cildo Meireles, riooir, 1976-2011.

(Fonte: Catálogo da exposição Entrevendo: Cildo Meireles, Sesc Pompeia, SP)

Revista Poiésis, Niterói, v. 21, n. 36, p. 175-206, jul./dez. 2020. (https://doi.org/10.22409/poiesis.v21i36.42766) 
Cildo Meireles - Então, por isso, porque eu tinha feito um gráfico ... bom, aí já tinha recursos, do Itaú Cultural; tinha uma equipe grande, tinha Filipe [Magalhães], depois a gente fez outro disco...

\section{Caroline Alciones - Esse aqui? [Pietro Bo]}

Esse disco você criou no contexto da exposição $O$ interior é no exterior ${ }^{18}$, que aconteceu na Casa de Vidro, mas, especificamente neste caso, como surgiu a ideia para essa obra no contexto de reinauguração da Casa de Vidro?

Cildo Meireles - Em 1977, o Bardi era o diretor eterno do MASP, tinha uma revista de artes, Guia das Artes, e tinha uma galeria de artes em São Paulo. Ele tinha um poder muito grande lá em São Paulo. $\mathrm{Na}$ ocasião, ele me convidou e depois me desconvidou para uma exposição no MASP. Ele me mandou uma carta que dizia assim: "Caro artista, tendo tomado conhecimento de que o senhor estaria fazendo uma exposição em outra instituição aqui em São Paulo, como a política do MASP é só mostrar trabalhos inéditos, lamento informar que tivemos que cancelar sua exposição."
Quando eu recebi a carta do MASP assinada pelo Bardi ... tentei entender, liguei para umas duas pessoas amigas e que conheciam melhor a política cultural lá de São Paulo e, provavelmente, foi porque eu tinha feito uma exposição com a Aracy Amaral. Aliás, ela tinha acabado de assumir a direção da Pinacoteca de São Paulo e me convidou para começar um novo trabalho para uma sala que, de uma certa maneira, tinha a ver com a Área Experimental daqui do MAM. Eu era um artista novo, na época com um trabalho novo, e aí eu mostrei o Caso de $\operatorname{Sacos}^{19}$ [na Pinacoteca de São Paulo]. Então, recebi essa carta do MASP, vi esse possível motivo, mas poxa, mesmo que fosse por esse motivo, não teria justificativa. Porque eu cheguei a ele da seguinte maneira: passou pelo Rio um colecionador de São Paulo, o Villares, Luís Villares, que foi o presidente da Bienal em 1979/80. Na casa de um amigo meu, o [Carlos] Scliar, ele viu uma coleção de desenhos meus e pediu ao Scliar para me passar o recado de que, quando eu fosse a São Paulo (eu ia praticamente todo mês para "mascatear"), se eu tivesse trabalhos, ele gostaria de ver. Então, quando eu estava lá, contatei, levei até a casa dele, ele escolheu um ou dois 
desenhos e me perguntou se eu já tinha feito exposição em São Paulo. Como eu disse que não, ele perguntou se eu não gostaria de fazer. "Claro que sim", eu disse. Isso em 1977, por aí. Talvez 1976. Ele pegou o telefone, ligou para o MASP. Ele era amigo, conselheiro do MASP, do MoMA, o Villares ligou e logo o Bardi atendeu. [...] Villares disse: "Estou aqui com um artista do Rio de Janeiro e penso que seria, talvez, uma boa ideia pensar em convidá-lo para uma exposição", e perguntou se ele [Bardi] poderia me receber. No mesmo dia à tarde, umas 16 horas, foi marcado.

Quando eu cheguei, ele me recebeu bem, tinha umas informações sobre uns trabaIhos, Inserções, não sabia muito bem o que era, mas enfim, eu já tinha feito Eureka/Blindhotland, mas não tinha nada publicado. Ele me recebeu cordialmente, marcou uma exposição para o ano seguinte, em 1977. Depois disso, a gente se falou uma vez por telefone, depois por carta e tive esse único contato pessoal com ele no começo de tudo, recomendado pelo Luís Villares, que era alguém que eu prezava e respeitava. Aí recebo essa carta. Mesmo que fosse essa briga dele com a Aracy, is- so não fazia sentido... Eu fiz uma carta, da qual eu me lembro dos termos, praticamente na íntegra... Ele [o Bardi] era o bam-bam-bam, era o "grande" do grupo lá em São Paulo. Isso [essa querela] me retardou [entrar em] São Paulo por anos.

$[\ldots]$

Caroline Alciones - Além de Desvio para o Vermelho, de 1984, outra obra que tem seu início datado na década de 1980 e que você concluiu em 1993 foi o Para Pedro. De forma semelhante a Através, Para Pedro apresenta a questão do atrito a partir da caminhada do sujeito que adentra a obra. Em que momento da concepção da obra você pensou no som?

Cildo Meireles - Para Pedro... fundamental. Começou com o som, na verdade, em 1984, entre novembro e dezembro de 1984. Meu filho mais velho, Pedro, estava com meses [de nascido] e meia-noite eu dava mamadeira a ele; depois ele só acordava às 6 horas. Eu derreti muitas [mamadeiras], porque botava em banhomaria e acordava com o som da televisão ligada. O que aconteceu? Um dia, eu tinha que dar mamadeira e acordei, pelas duas da manhã, mais ou menos, com o cheiro 
da mamadeira derretida e ouvindo o som de alguém batendo azulejos, lá naquele Centro Empresarial Rio, na Praia de Botafogo, sabe? O som assim ... de ladrilheiros, duas e pouca da manhã.

[...]

O Pedro era bem novinho ainda, estava começando a ser desmamado, e eu tinha que colocar ele para mamar. Conclusão: eu acordo, vou lá e desligo [o fogão]. Boto [a mamadeira] para esfriar um pouco e aí eu me lembrei de uma história que, meses antes, eu tinha ido à Colômbia; o Antonio Caro ${ }^{20}$ também estava [conosco]. Um dia, nos levaram para visitar uma cerâmica que era cravada em umas montanhas em cavernas perto de Medelín. Teve uma hora que eu estava andando e comecei a ouvir um som incrível. Fui me aproximando, era um pátio e tinha umas vinte mulheres sentadas quebrando o umbigo da cerâmica... sabe, o umbigo? Sempre fica uma rebarbazinha e, então, você quebra aquilo com outra cerâmica e aquilo virava a maior batucada, porque você acaba fazendo aquele ritmo mesmo, a chamada música de trabalho, para ajudar a pilar. Eu fiquei com aquilo na cabeça e acordei com um som parecido, que era o do azulejo, do ladrilho, aquele som de coisa cozida sendo quebrada, barro cozido... foi assim que começou o Para Pedro, dessas continuidades de superfícies. Mas começou com o som da pedra quebrando, que é o som da peça mesmo.

[...]

Depois, a televisão já tinha saído do ar. Naquela época, não tinha televisão com canal pago. Então, duas e pouca da manhã, só tinha aquele chuvisco e aí tinha uma certa continuidade da fragmentação da pedra. Esse trabalho é muito legal; eu gosto dele porque foi o primeiro trabalho que eu pensei depois que o Pedro nasceu. Por isso é Para Pedro. E Pedro também é pedra. Então, por isso eu penso que ele é todo redondo. (Fig. 9)

[...]

[Aparece uma imagem do projeto de Através] (Fig. 10)

Caroline Alciones - O Através me chamou muito a atenção porque, na primeira vez que eu entrei na obra em Inhotim, estávamos só eu e uma amiga caminhando. Três meses depois, eu levei uma turma de 25 estudantes da Escola Sesc de Ensino Médio, daqui do Rio. Era um grupo de 27 a 30 pessoas caminhando a obra... a obra 


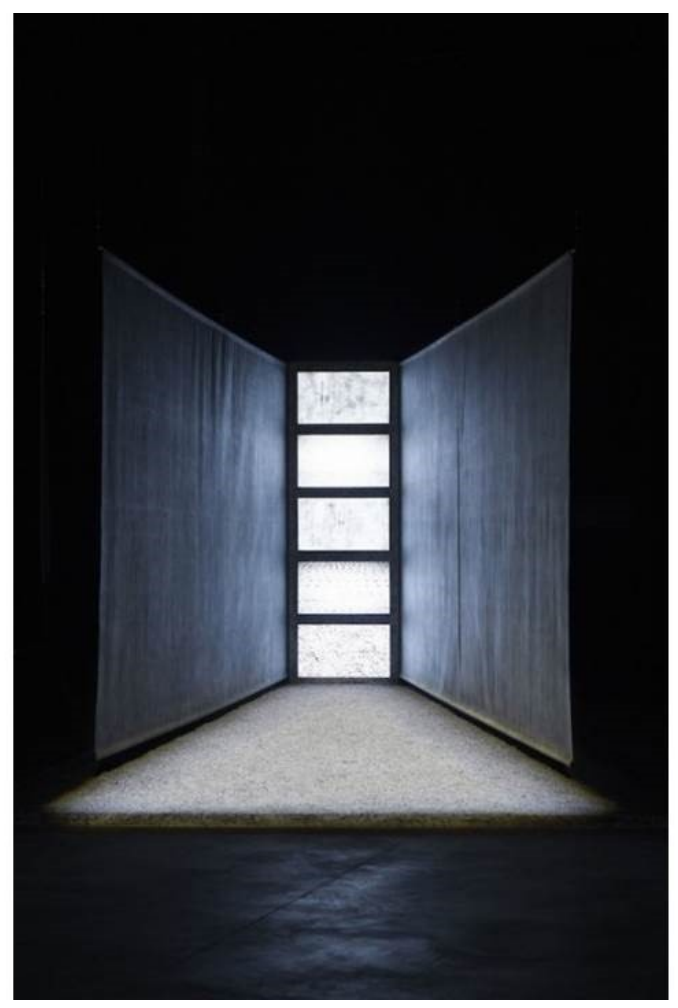

Fig. 9 - Cildo Meireles, Para Pedro, 1984-1993.

(Foto: Agostino Osio, Fondazione HangarBicocca;

Fonte: https://www.galerialuisastrina.com.br/artistas/cildo-meireles/) 


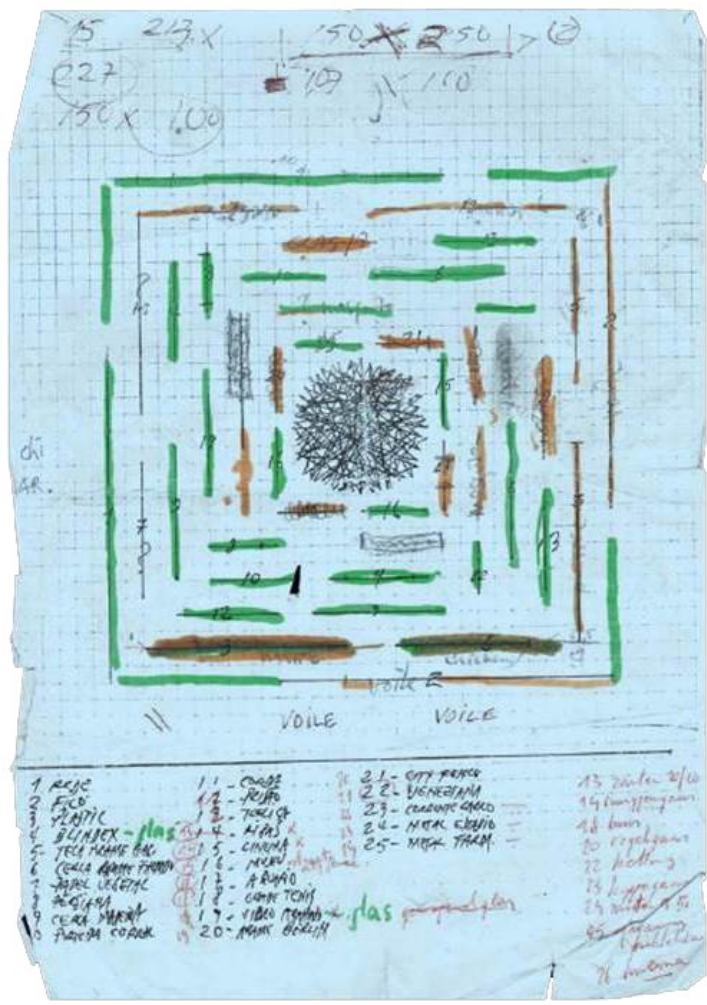

Fig. 10 - Cildo Meireles, projeto para Através, 1989.

(Fonte: Mango Discipline, 2018) 
se transformou. Acontece também de você, enquanto artista e criador, se espantar com o som de determinadas obras quando elas deixam de ser projeto para se concretizarem? Qual é a história do Através?

Cildo Meireles - O som é uma dessas coisas. Você pensa um trabalho, às vezes convive anos... Por exemplo, há um tempo, em 2004, eu mostrei um trabalho que eu pensei o projeto em 1969, foram 35 anos, e aí você pensa que você conhece... [...]

Na primeira vez que montamos o Através em Kortrijk, uma cidade da Bélgica, eu conheci o Trudo, que me ajudou na montagem da obra. Um dia, a Catherine de Zegher, que era diretora desse Kanaal [Art Foundation], onde a gente fez [o Através], e me falou assim: "Cildo, olha, na Bélgica é muito difícil você pegar uma pessoa para ajudar como assistente na montagem. Mas tem um artista jovem, que conheceu uns trabalhos teus e ficou interessado em te ajudar." Ele ganharia menos dinheiro em qualquer tipo de emprego informal do que o segurodesemprego daria para ele. Como ela falou que ele estava interessado, ela fez um jantar na casa dela para nos apresentar.
Catherine de Zegher continuou: "Só que tem uma curiosidade. Ele nasceu no mesmo dia e no mesmo mês que você, mas ele é 14 anos mais novo." Tivemos o jantar e, na saída, eu estava em um hotel no centro de Kortrijk e a casa dela era um pouco fora; ele me ofereceu carona. Era um Renault que parecia um triciclo, um carrinho baixinho, um furgãozinho que eu apelidei de limusine. A gente quase não cabia dentro... Mas enfim, isso foi no primeiro dia. A gente se conhecia há duas horas, ele foi me levar no hotel e, no caminho, paramos em um bar: "Trudo, agora me diz, no teu trabalho, o que você está fazendo?" E aí ele começou a descrever uns trabalhos que eram umas estantes, umas esculturas, cada uma cheia de livros. Os livros sempre mencionavam no título o nome de uma mulher, Marie, Lucie, Jaqueline, enfim. E [as estantes] eram curvas, um pouco como aquela coisa do [Oscar] Niemeyer e então ele explicou que havia uma variedade de nomes. Mas, enfim, isso foi no primeiro dia; a gente sempre manteve a amizade.

[Vendo a planta-baixa de Através] 
Eu cheguei com um papelzinho dobrado no bolso para fazer o Através. Era o primeiro plano que eu levei para o Trudo. 0 Trudo não acreditava... Esse já é um segundo [mostrando o catálogo Mango Discipline], já é um melhorado, diferente daquele que eu fiz no hotel. Aquele era uma folha de bloco de anotação, mas acho que era mais precário do que esse que está aí. E tinha as dobras.

[..] Mais tarde, ele [Trudo] confessou não ter acreditado que dali [daquele papelzinho dobrado] fosse sair alguma coisa. Mas estava tudo lá. Eu me lembro que o JeanClaude Bernardet, crítico de cinema, contou uma vez, em uma aula sobre cinema brasileiro e cinema novo, lá em Brasília, que um aluno teria dito: "Eu não compreendo, como o cara fazia um filme assim [precário] e o filme seguinte, já era esse aqui?... tem um salto." E o Jean-Claude teria respondido: "É que entre um filme e o outro, o cara fez vários filmes na cabeça, que não teve condições de materializar. ${ }^{21}$ É a mesma história do pintor chinês e do imperador. Não tem a história do galo? Essa história eu acho brilhante. Um imperador chinês, um belo dia, chega a um pintor e fala:
"Olha, eu queria encomendar um galo".

O pintor respondeu: "Com um sinal particular? Qualquer coisa assim?"

Imperador: "Não, um galo."

Naquela época, quando ainda existia liberdade artística, o imperador disse: "E quando eu posso vir buscar?"

Daí o artista falou: "Daqui a oito anos."

O imperador: "Pô?!". Mas naquela época ainda havia respeito por artista, o imperador não discutiu e foi embora.

Oito anos depois, ele voltou e falou: "Oi, vim buscar meu galo."

"Eu sei. Por favor, se sente." O artista pegou uma tela mostrou e o imperador perguntou:

"Mas o galo não está pronto?

Pintor: "Não, ele não está pronto."

"Mas você ainda não fez o galo? O que você ficou fazendo nesses oito anos?", perguntou o imperador.

"Treinando para fazer o galo", respondeu o pintor. A gente tem que aprender com esses chineses, essas ideias artísticas. Outra sabedoria...

Caroline Alciones - Sem dúvida... Além da questão da polifonia, algumas de suas obras criam um emaranhado a partir de elementos sonoros, como as músicas mais 
tocadas dos Beatles em Liverbeatlespool, e aquilo que toca em todas as rádios possíveis de serem sintonizadas quando Babel está em exposição. Você poderia falar um pouco deste emaranhado, deste sólido sonoro e do contexto de criação de Babel?

Cildo Meireles - É uma cacofonia. Ele bate com Liverbeatlespool. Mas aí... é som ainda. [...] Babel é som também.

[...]

O Babel nasceu na Canal Street 22 (Fig. 11), no começo dos anos 1990, porque às vezes eu passava pela calçada e via aquelas microlojas, tinha rádios empilhados. Eu pensei em fazer uma coisa que seria mais, vamos dizer, contemporânea com esses rádios, porque você podia escolher um modelo que iria caber nessa coluna, toda certinha, como tijolinhos. A primeira vez que eu pude fazer isso foi em 2000/2001 no [Museum of Contemporary Art] Kiasma [em Helsinque, Finlândia]. Era a segunda exposição que eu iria fazer lá, eu já tinha feito uma exposição individual em 1999, que foi o $K u k k a k a k k a$ e depois em 2000/2001, essa eu acho que foi em 2001. A Maaretta [Jaukkuri] me convidou para uma exposição que era algo grande, que ela fazia de três em três anos e eu acabei fazendo. Então, fui a uma primeira reunião [no Kiasma]. Decidido como seriam as coisas, foram constituídos grupos para visitar as feirinhas e os mercados de segunda mão nos diferentes lugares da Finlândia, sabendo-se que a Finlândia tem 5 milhões de habitantes. A primeira versão é menor. Eu tive que fazer pesquisa em menos de 10 dias. Eu e mais dois rapazes, um que estaria prestando serviço militar, mas teve a possibilidade de optar por serviço social, voluntário, e outro que era um técnico do museu. [...]

Aí teve essa primeira reunião em que se decidiu que formaríamos equipes que iriam pesquisar e eu voltei para a montagem, umas duas semanas antes [da inauguração], no Kiasma, que é um cubo perfeito mesmo. [...] Eu cheguei e estava tudo vazio, com aqueles rádios todos, que a gente havia conseguido, no chão... e a coisa adquiriu, para mim também, um interesse que virou uma coisa meio arqueológica, meio antropológica também, porque os rádios mais antigos eram os mais pesados. Eram móveis... então eles, naturalmente, os mais pesados, iam mais para baixo, iam criando uma espécie de base e, naturalmente também, iam ficando menores, 


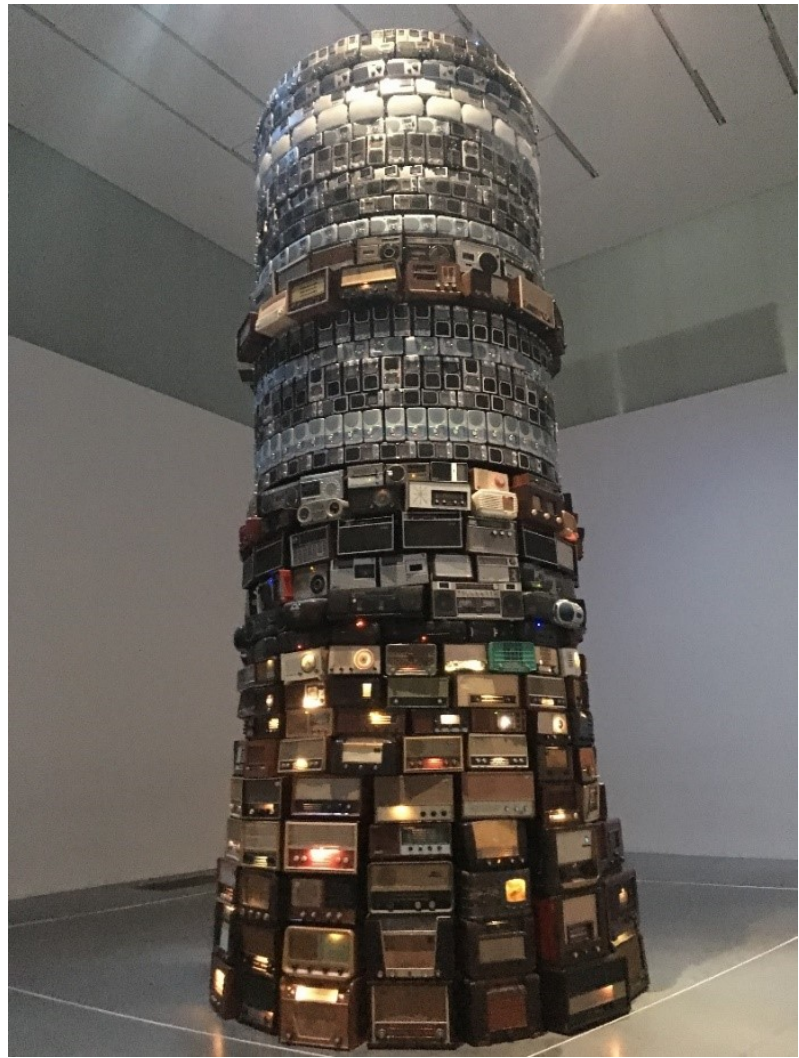

Fig. 11 - Cildo Meireles, Babel, 2001.

(Fonte: Hélio Branco) 
menores, mp3 também, mas menores, o que acentuava a ideia de perspectiva. A estrutura era um cilindro, mas em função disso...[acabou acentuando a ideia de perspectiva]. Isso foi um ganho para a peça. A outra coisa foi que virou uma espécie de recorte enciclopédico do objeto rádio.

Caroline Alciones - Essa variedade de rádios de distintos tamanhos e épocas acaba conferindo um quê de coleção à obra?

Cildo Meireles - Pois é, a gente evitou. Porque era difícil. Porque é um quebracabeças. Às vezes você precisa de um rádio desse tamanho, dessa profundidade... O Rubens é que se divertia. Ele e o Max.

(Rubens) "Catando rádio por aí... Fui a muitas feiras".

Cildo Meireles - Aqui, em São Gonçalo, Caxias... O Max, meu irmão, procurava rádios em Brasília e em São Paulo. Em São Paulo, teve uma tragédia embutida. A gente chegou a um lugar de colecionadores e eles falaram de um português comerciante, cujo apelido era Pica-pau. O Sr. Pica-pau tinha uma coleção de uns 15 mil rádios. Ele tinha um comércio e gostava de rádios. Começou a colecionar e chegou um momento em que ele comprou um prediozinho de três ou quatro andares em São Paulo, onde guardou toda essa coleção. Ele passava temporadas de dois, três meses em Portugal. Ele tinha família lá. Mas o que acontece é isso. Ele fazia essas viagens. Ele comprou esses rádios todos [que compunham a] coleção dele, botou no prédio, contratou um vigia e foi para Portugal. Voltou três meses depois e o prédio estava quase vazio. O vigia se conectou com a rapaziada do crime, passou um caminhão... O cara ficou destroçado. Ele tinha um sítio perto de São Paulo e levou o restante [dos rádios] para lá. A ideia dele era fazer uma doação para a constituição do museu do rádio em São Paulo. Ele tinha preciosidades mesmo. Um dia, o Sr. Pica-pau lembrou de um rádio, foi procurar e, quando chegou no sítio, os cupins tinham atacado o rádio. Então, de repente, uma coleção de 15.000 rádios se pulverizou. Não sei o que aconteceu depois... Brasil, né?!

Eu tenho um projeto de museu... em 2010, eu até fiz uma brincadeira, que é uma tela, que está por aí, que é o projeto de um buraco para jogar político ${ }^{23}$. Mas na 
verdade, antes tinha uma anotação que era uma sugestão para um museu aqui do Brasil. Em Brasília, porque tem essa distância extrema entre o mar e a superfície. O Planalto Central é uma chapa quente, o que explica a vegetação, toda calcinante. Mas enfim, era isso: tinha que fazer um buraco grande e jogar todo o acervo, arte brasileira, direto ali dentro. Porque, se não, você fica gastando dinheiro com conservação, climatização, desinfecção, gente trabalhando, coisa de trabalho. Então acaba logo, porque é uma questão de tempo, vai tudo [acabar] cedo ou tarde. Bom, cedo ou tarde não vai salvar mesmo coisa nenhuma.

\section{Notas}

${ }^{1}$ Registramos nossos agradecimentos ao artista Cildo Meireles pela generosidade em nos receber em seu ateliê e de dispor seu tempo para nos atender. Agradecemos também à acolhida de seus assistentes - Rubens Teixeira dos Santos, Bernardo Damasceno e Stefania Paiva, sempre muito receptivos e colaborativos.

${ }^{2}$ O mestrado foi cursado no Programa de PósGraduação em Estudos Contemporâneos das Artes da Universidade Federal Fluminense, sob orientação do Professor Doutor Luiz Sérgio de Oliveira, com a dissertação Ao Redor e Através: um estudo crítico da obra Através de Cildo Meireles, defendida em junho de 2016. O doutorado está em andamento no Programa de Pós-Graduação em Artes Visuais da Escola de Belas Artes da Universidade Federal do Rio de Janeiro, sob orientação da Professora Doutora Maria Luisa Távora e coorientação do Professor Doutor Tato Taborda.

${ }^{3}$ Em uma referência a Estudo para espaço (1969), Estudo para tempo (1969) e Estudo para espaço/tempo (1969).

${ }^{4}$ Eureka e Expeso são duas das quatro partes de Eureka/Blindhotland (1970-1975). Eureka é constituída pela balança com dois pratos, sobre os quais pesam, em um, duas barras de madeira medindo $10 \times 10 \times 30$ $\mathrm{cm}$, enquanto no outro prato há uma cruz de medidas análogas ao par de barras, exceto pela subtração do trecho que une as partes da cruz. 0 fiel da balança, por sua vez, assevera o mesmo peso para volumes que são distintos. Expeso é a terceira parte da obra, constituindo-se pela gravação do som de oito combinações de pesos das esferas em queda livre, a partir de três situações diferentes: altura da queda, a distância do microfone e o peso da esfera. 
${ }^{5} \mathrm{O}$ astrônomo e matemático alemão August Ferdinand Möbius (1790-1868), dentre outros feitos, recebeu os créditos pela criação do espaço topológico obtido a partir da colagem das extremidades de uma fita (ou faixa), após torção sob seu próprio eixo - a fita (ou faixa) de Moebius. Apesar dos créditos a Möbius, tal estudo teria sido antecipado, quatro anos antes (1861), pelo matemático Johann Benedict Listing (1808-1882). Porém, foi Möbius quem desenvolveu a definição de não-orientabilidade ainda em uso atualmente. CRANNELL, Annalisa; FRANTZ, Marc; FUTAMURA, Fumiko. Perspective and Projective Geometry. Princeton e Oxford: Princeton University Press, 2019.

${ }^{6}$ Cildo Meireles relatou ter lido em um artigo que, à medida que os circos iam se desagregando, o dono do circo saldava sua dívida com os artistas dando um pedaço da lona para cada um. Cada artista passava a fazer seu espetáculo solo naquele pedaço de lona, cobrando ingresso para tanto. E, assim, o circo ia se desagregando. Tal procedimento teria ficado conhecido como pano-de-roda, cuja ideia de autonomia e independência para funcionamento nos mais distintos lugares, o artista afirma existir por trás de suas instalações.

7 A Velha Contrabandista de Stanislaw Ponte Preta, pseudônimo de Sérgio Marcos Rangel Porto, narra a história de uma idosa que todos os dias atravessava uma fronteira de lambreta, carregando um grande saco em sua garupa. Desconfiado, um funcionário parava a idosa todos os dias, sem acreditar que ela carregava somente areia naquele saco. Até que um dia, convencido de havia algo de errado e sem conseguir descobrir o que, de fato, a senhora estaria contrabandeando, o experiente fiscal, prometendo não contar a ninguém nem tampouco impor qualquer sanção, propôs que a senhora contasse aquilo que ela contrabandeava. A senhora aceitou o acordo e sanou a dúvida do fiscal: "é a lambreta".
${ }^{8}$ Em São Paulo, Elemento desaparecendo / Elemento desaparecido (passado iminente) (2000-2002) foi realizado na exposição Futuro do Presente, organizada pelo Itaú Cultural em 2004.

${ }^{9}$ A exposição para a qual Cildo Meireles havia sido convidado no Texas não ocorreu. Assim, Desvio para o Vermelho (1967-1984) foi exposta, pela primeira vez, no Museu de Arte Moderna do Rio de Janeiro (MAMRJ) em 1984.

${ }^{10}$ Le Creux de l'Enfer - Centre d'Art Contemporain fica na cidade de Thiers, região central da França.

11 A Galleria Continua foi fundada em 1990 por Mario Cristiani, Lorenzo Fiaschi e Maurizio Rigillo, ocupando um espaço inusitado no formato de um cinema em San Gimignano, na Itália. Entre 2004 e 2020, a Galleria Continua abriu filiais em Beijing (China), Paris (França), Havana (Cuba) e Roma (Itália).

${ }^{12}$ A Galerie Lelong \& Co. representa artistas contemporâneos dos Estados Unidos, da América Latina, Europa, Ásia e Austrália. A galeria possui uma sede em Nova York e outra em Paris.

${ }^{13}$ VARIOUS ARTISTS; JACOBS, Loes (Ed.). Mango Discipline (catálogo publicado a partir da exposição $Q \&$ A). Gent, Bélgica: Various Artists; San Gimignano, Italia; Galleria Continua, 2018.

${ }^{14} \mathrm{O}$ catálogo reúne em quatro capítulos ou dimensões - Mathematics, Shit, Value e Water -, obras de Cildo Meireles e Trudo Engels em diálogo. Cabe, ainda, observar que Various Artists trata-se de um coletivo, do qual Trudo Engels é cofundador. Tal Various Artists teve início com 24 artistas fictícios e, por volta de 2008, teria se consolidado como um coletivo artístico a partir das distintas práticas daqueles que integram o coletivo. A partir de então, Trudo Engels não atua 
mais como artista a partir de seu próprio nome, mas a partir de Various Artists.

15 II Bienal de Johanesburgo, em 1997.

${ }^{16}$ Banda sonora do disco na qual constam os sons das águas.

${ }^{17}$ A montagem da obra a que se refere Cildo Meireles se deu no contexto da exposição Ocupação Cildo Meireles (10 ${ }^{\mathrm{a}}$ Edição do Projeto Ocupação), que contou com a curadoria de Guilherme Wisnik, no Itaú Cultural em São Paulo.

${ }^{18}$ A exposição teve curadoria de Hans Ulrich Obrist e foi realizada no Sesc Pompeia e na Casa de Vidro, ambos na cidade de São Paulo, em 2013. A mostra foi uma realização do Instituto Lina Bo e P. M. Bardi e do Serviço Social do Comércio (Sesc).

${ }^{19}$ Exposição Casos de Sacos - Pinacoteca do Estado de São Paulo, São Paulo, Brasil (1977).

${ }^{20}$ Antonio Caro (1950) é um dos principais artistas colombianos ligados ao conceitualismo.

${ }^{21}$ Cildo Meireles chegou a estudar cinema no Centro Integrado de Ensino Médio (CIEM/UNB, Brasília) em 1965.

${ }^{22}$ Localizada em Chinatown, na cidade de Nova York (EUA).

${ }^{23}$ Buraco para jogar políticos desonestos (2010).

\section{Referências}

CRANNELL, Annalisa; FRANTZ, Marc; FUTAMURA, Fumiko. Perspective and Projective Geometry. Princeton e Oxford: Princeton University Press, 2019.

GALERIA LUISA STRINA. Cildo Meireles. Informações sobre a obra Para Pedro. Disponível em https://www.galeria luisastrina.com.br/artistas/cildo-meireles/. Acesso em 10/2/2020.

SESC POMPEIA. Entrevendo: Cildo Meireles. (catálogo da exposição) São Paulo: Sesc Pompeia, 2019.

UNIVERSES IN UNIVERSE. Cildo Meireles. Informações sobre a obra Elemento desaparecendo / Elemento desaparecido (passado iminente). Documenta 11, Fredericianum: Kassel (Alemanha), 2002. Disponível em http://universes-in-universe.de/ car/documenta/11/frid/e-meireles.htm. Acesso em 7/2/2020.

VARIOUS ARTISTS; JACOBS, Loes (Ed.). Mango Discipline: Cildo Meireles e Various Artists. (catálogo publicado a partir da exposição $Q \& A$, realizada em 2015). Gent, Bélgica: Various Artists; San Gimignano, Italia: Galleria Continua, 2018. 